\title{
Dream and Representation
}

\section{Scarpelli G*}

Università di Modena e Reggio Emilia, Italy

*Corresponding author: Giacomo Scarpelli, Dipartimento di Studi Linguistici e Culturali, Università di Modena e Reggio Emilia; Largo Sant'Eufemia 19, Modena 41121, Italy, Tel: +390592055906; Email: giacomo.scarpelli@unimore.it

\section{Mini Review}

Volume 4 Issue 4

Received Date: September 21, 2021

Published Date: October 11, 2021

DOI: $10.23880 /$ phij-16000199

\section{Abstract}

This short article analyses the relationship between dreams and stories and the underlying existential significance of both. Man is not the only animal who dreams, but he is the only living being who can communicate to his fellow creatures what he dreams and invents, through words and images.

Keywords: Dream; Freud; Nietzsche; Greek Culture; Imagination

Dreams are a content of images, facts and states of mind that appear during the psychic activity exercised by the individual in sleep. However, are not images, facts and moods precisely the essential components of a story? Would we be wrong, therefore, if we were to venture to consider dreams as unorganized representations of stories? Immediately afterwards, there is another question: what exactly do we mean when we talk about stories?

A story is a collection of images, facts and moods that makes up an episode of life and contains an underlying meaning; it needs to be discovered since, while there are few unconscious ideas (birth, love and death, for Freud) and very few existential feats (those of Cinderella and Thumbelina, for Scott Fitzgerald), the symbols and variants that conceal them are infinite.

Freud called his founding work Traumdeutung ("Interpretation of Dreams") and not something like Exegese von Traumphänomenologie ("Exegesis of Dream Phenomenology"); this choice of title reflecting his sensitivity to a popular way of feeling and thinking and eschewing academic name pedantry; the father of psychoanalysis knew that the dream is precisely a form of unconscious narration, generated by intimate drives and emotions that belong to the entire human species: Traum and Trauma are contiguous terms, even if they do not necessarily have a common etymology ${ }^{1}$

The Greeks, aware of the alogical and tragic background of existence, told themselves myths, stories of heroes facing inscrutable Fate, and of capricious gods projecting the psyche. And often the meaning of these tales was the mystery itself, the inaccessible árreton. In sleep as well as in wakefulness we therefore need stories, we are greedy for them, perhaps simply to make sense of existence, of what has been and what is, in an anxiety to know what will be. The situation of obsessive uncertainty forces a perpetual forward tension. Unhappiness, or at least the sense of inadequacy and the search to overcome it, constitute the substratum of both the dreamlike action and the narrative progression.

The artistic endeavor of a narrator should aim precisely at ensuring that the reader's consciousness is immediately stirred up by the questions "what will happen?" and "how will this story end?". This is an attempt to keep the suspension alive within a story, which cannot be dismissed as a mere entertainment gimmick.

The question of "how will it end?", a reflection of the

1 Sigmund Freud, Traumdeutung (Leipzig and Wien: Deuticke, 1900). Traum means dream, while the word Trauma is identical in German, English and Italian. 
trepidation that always accompanies Homo sapiens, is instead often - in literature and in cinema - taken into account as an artistic lowering. And this is a serious mistake. A few examples are enough to demonstrate this. What is Dostoevsky's Crime and Punishment if not the story of a murder, in which the reader yearns to know whether Raskolnikov will be unmasked by the examining magistrate Porfiry Petrovich? And again, just to mention the "hooks" of other immortal masterpieces: will Ulysses manage to return to Ithaca, re-embrace Penelope and get rid of the Suitors? Will Dante manage to find the lost Beatrice at the end of his journey to the Afterlife? The "what will happen?" is therefore not just a narrative device, but a basic creative component, for the reason that not knowing and the desire to know is a constant part of human life.

The enigma of "what will happen?" is supposed to lose its importance only when death approaches. Consciousness would then turn in on itself and turn back to the past, in a kind of backward dream.

We might venture to speculate that, after all, the pressing question of what is to come is an equivalent of the principle of tension towards wish fulfillment that Freud speaks of in reference to dreams. As it happens, and as Darwin teaches dogs, cats and monkeys and numerous other mammals and birds also dream (experienced episodes, the conquest of food, escape from a predator). They are therefore subject to the elaboration of imaginative content, which in the light of what has been considered so far, we can define as the "narrative" activity of sleep. Man, however, the self-conscious animal, is the only living being capable of recreating stories during waking hours that excite the imagination of the listener, reader or spectator. This gift is not developed in everyone, but only in the professional storyteller, since Nietzsche's lesson applies: "in dreaming we use too much of our artistic capacity - and therefore often have too little of it during the day". 2

"Images are good for the soul! They are its true nourishment!", proclaimed the romantic philosopher and scientist Franz von Baader. ${ }^{3}$ A story is told through images, which are produced by the psyche during sleep. When we are awake we have to recreate the images through words. The eidetic is precisely the narrator's ability to visualize and evoke images, scenes, atmospheres and figures for the benefit of the reader, and to transfer them onto the page by means of words. The cinema tells stories through images that

2 Friedrich Nietzsche, Menschliches, Allzumenschliches, 2 voll., (Chemnitz: Schmeitzler, 1878-1879); trans. by R.J. Hollingdale, Human: All too Human (Cambridge: Cambridge University Press, 1996) p. 358.

3 Franz von BAADER, Tagebücher aus den Jahren 1786-1793, in Sämmtliche Werke (Leipzig: Bethmann, 1850), I, p. 26. are closer to dreams than others. Hence its great popular appeal.

In the era of the triumph of technology, however, the individual risks becoming a persecuted person, as he is bombarded by reproduced, modified and amplified images. Suffice it to say that in 1820 man was only allowed to contemplate drawings and paintings. In 1920, even photographs and stills from the first cinematograph. A century later, digital and virtual images give the illusion of an absolutely fantastic creativity within everyone's reach, when in fact it is technology that makes man its victim.

Should we return to the power of the mind to visualize and the power of the word to evoke? Is it perhaps too late?

I sogni, nella definizione corrente, sono un contenuto d'immagini, di fatti e di stati d'animo che si manifesta durante l'attività psichica esercitata dall'individuo nel sonno. Tuttavia, immagini, fatti e stati d'animo non sono precisamente $i$ componenti essenziali di una storia? Di conseguenza, sbaglieremmo qualora ci azzardassimo a considerare $i$ sogni rappresentazioni non organizzate, anzi decisamente scombiccherate, di storie? Subito dopo, ci troveremmo di fronte a un nuovo interrogativo: cosa intendiamo esattamente quando parliamo di storie? Una storia è un insieme d'immagini, fatti e stati d'animo che compone un episodio di vita e che contiene un significato. Un significato sottostante che occorre scoprire, dal momento che, se poche sono le idee inconsce (nascita, amore e morte, per Freud) e pochissime le imprese esistenziali (quelle di Cenerentola e di Pollicino, per Scott Fitzgerald), infiniti sono i simboli e le varianti che le celano.

Freud chiamò la propria opera fondatrice Traumdeutung (Interpretazione dei sogni) e non qualcosa come Exegese von Traumphänomenologie (Esegesi della fenomenologia onirica); fu una scelta di titolo fatta a ragion veduta, che rispecchiava la sensibilità per un modo di sentire e di pensare popolare e rifuggiva la pedanteria denominativa accademica; il padre della psicoanalisi sapeva che il sogno è appunto una forma di narrazione inconscia, generata da pulsioni ed emozioni intime che appartengono all'intera specie umana: "Traum" e "Trauma" sono termini contigui, pur se non hanno necessariamente etimologia comune. ${ }^{4}$

I greci, consapevoli del fondo alogico e tragico dell'esistenza, si raccontarono $i$ miti, storie di eroi che affrontavano il fato imperscrutabile, e di dei capricciosi proiezione della psiche. E spesso il significato di quelle favole era il mistero stesso, l'árreton inaccessibile. Tanto nel sonno quanto nella veglia abbiamo quindi bisogno di storie, ne siamo

4 S. Freud, Traumdeutung, Leipzig-Wien 1900 (L'interpretazione dei sogni, traduz. di E. Fachinelli e H. Trettl, Torino 2010). Traum significa sogno, mentre il vocabolo "trauma" è identico in italiano e in tedesco. 
avidi, forse semplicemente per dare un senso all'esistere, a ciò che è stato e a ciò che è, in un'ansia di conoscere ciò che sarà. La situazione d'incertezza ossessiva costringe a una perenne tensione in avanti. Per farla breve, l'infelicità, o quanto meno il senso di inadeguatezza e la ricerca di un suo superamento costituiscono il sostrato tanto dell'azione onirica quanto del progredire narrativo.

L'impegno artistico di un narratore dovrebbe puntare precisamente a far sì che nel lettore si agitino, immediatamente sotto la linea di galleggiamento della coscienza, le domande "cosa accadrà?" e "come andrà a finire questa vicenda?". Un intento, questo, di mantenere vigile la sospensione all'interno di una storia, che non può essere liquidato come un mero espediente d'intrattenimento. La questione del "come andrà a finire?", riflesso della trepidazione che sempre accompagna l'Homo sapiens, viene invece spesso - nella nostra letteratura e nel nostro cinema - tenuta in conto di un abbassamento artistico. Ed è un grave errore. Per dimostrarlo basterebbe qualche esempio. Delitto e castigo di Dostoevskij cos'è se non la storia di un omicidio, in cui il lettore anela a sapere se Raskolnikov verrà smascherato dal giudice istruttore Porfirij Petrovič? E ancora, tanto per citare i "tiranti" di altri capolavori immortali: Ulisse riuscirà a tornare a Itaca, a riabbracciare Penelope e a liberarsi dei Proci? Dante riuscirà alla fine del suo viaggio nell'Aldilà a ritrovare la perduta Beatrice? Renzo e Lucia riusciranno a superare tutte le avversità che si oppongono alle loro nozze? Il "cosa succederà" non è perciò un qualunque artificio narrativo, bensì una basilare componente creativa, per il motivo che il non sapere e il desiderio di sapere è parte costante della vita dell'uomo.

L'enigma del "cosa accadrà?" si è supposto venga a perdere la sua importanza solamente quando la morte si avvicina. Allora la coscienza si ritrarrebbe su se stessa per volgersi verso il passato, in una specie di sogno a ritroso. Potremmo arrischiarci a ipotizzare che in fondo, il pressante interrogativo sul che succederà si riveli un equivalente del principio di tensione verso l'appagamento del desiderio di cui parla Freud in riferimento al sogno. Come che sia, e come Darwin insegna, e Aristotele prima di lui, anche $i$ cani, i gatti e le scimmie e numerosi altri mammiferi e uccelli sognano (episodi vissuti, la conquista del cibo, la fuga da un predatore). Sono quindi soggetti all'elaborazione di contenuti immaginifici, che alla luce di quanto considerato fin qui, possiamo definire l'attività "narrativa" del sonno. L'uomo però, l'animale autocosciente, pare l'unico in grado di ricreare racconti durante la veglia. Questa dote non è sviluppata in chiunque, ma soltanto nel narratore di professione, poiché vale la lezione di Nietzsche, secondo cui «noi consumiamo nel sogno troppa arte - e ne siamo perciò di giorno così poveri».

Una storia si racconta per immagini, che nel sonno vengono irraggiate dalla psiche. "Le immagini fanno bene all'anima! Sono il suo vero nutrimento!», proclamava il filosofo romantico e scienziato Franz von Baader, e da svegli, tocca alla parola ricrearle. L'eidetica è precisamente la capacità propria del narratore di visualizzare ed evocare a beneficio del lettore immagini, scene, atmosfere e figure, e di trasferirle sulla pagina per mezzo della parola. E di qui eventualmente rinviarle a una realizzazione ottica: il cinema narra storie per immagini che più di altre si avvicinano visivamente al sogno. Ne discende la sua grande presa popolare.

Nell'era del trionfo della tecnologia, tuttavia, l'individuo, bombardato dalle immagini riprodotte, modificate $e$ amplificare, rischia di trasformarsi in un perseguitato. Basti pensare che nel 1820 all'uomo era dato di contemplare soltanto disegni e dipinti. Nel 1920 anche fotografie e fotogrammi del primo cinematografo. Un secolo dopo, le immagini digitali e virtuali elargiscono l'illusione di una creatività assolutamente fantastica e alla portata di tutti, mentre in verità è la tecnologia a fare dell'uomo la propria vittima. Sarebbe il caso di tornare alla potenza della mente nel visualizzare e alla potenza della parola nell'evocare? Forse è troppo tardi? 